\title{
Influence of Meloidogyne javanica parasitism on soybean development and chemical composition
}

\author{
Carla Marcondes Castanheira ${ }^{1 *} \mathbb{D}$, Claudia Regina Dias-Arieira ${ }^{1,2}$ (D) Elza louko Ida ${ }^{3}$ [D, Heloísa Gabriel Falcão ${ }^{3}$ \\ and Beatriz Cervejeira Bolanho Barros ${ }^{2,4}$ (D)
}

\begin{abstract}
Background: Soybean is a major economic crop worldwide, but its yield and quality are greatly affected by root-knot nematode infection. This study aimed to assess the effects of Meloidogyne javanica parasitism on soybean growth, yield, and quality. Soybean plants were inoculated with 0, 1000, 2000, or 4000 eggs + second-stage juveniles (J2) of M. javanica and evaluated for vegetative and nematode parameters. Grains from each treatment were analyzed for yield, proximate composition, total phenolic content, total flavonoid content, isoflavone profile, and antioxidant capacity.

Results: Plants free of nematodes had lower vegetative growth and higher yield than nematode-infected plants. The maximum estimated reproduction factor was 34.85, achieved by inoculation of 2433 eggs + J2. Moisture, fiber, and protein contents decreased with increasing inoculum levels. Lipid content increased with inoculum level until reach-

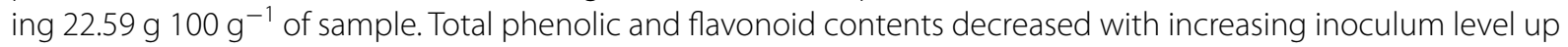
to about 2000 eggs $+J 2$ and then increased until reaching $219.20 \mathrm{mg}$ gallic acid equivalents $100 \mathrm{~g}^{-1}$ of sample and $121.67 \mathrm{mg}$ quercetin equivalent $100 \mathrm{~g}^{-1}$ of sample, respectively, at 4000 eggs $+\mathrm{J} 2$. A similar behavior was observed for antioxidant capacity determined by the 2,2-diphenyl-1-picrylhydrazyl radical scavenging, superoxide radical scavenging, and ferric reducing antioxidant power assays. The highest contents of malonylgenistin $\left(539 \mathrm{mmol} \mathrm{g}^{-1}\right)$, acetylglycitin $\left(106 \mathrm{mmol} \mathrm{g}^{-1}\right)$, and genistin $\left(87 \mathrm{mmol} \mathrm{g}^{-1}\right)$ were found in grains from plants inoculated with 4000 eggs $+J 2$.

Conclusions: M. javanica inoculum level affected soybean development, grain production, yield, composition, and antioxidant capacity.
\end{abstract}

Keywords: Root-knot nematode, Biotic stress, Oilseed, Antioxidant capacity, Isoflavones

\section{Background}

Soybean (Glycine max (L.) Merrill) is one of the most important oilseeds and food crops in the world because of its great production potential, chemical composition, and high nutritive value. This legume crop has a

\footnotetext{
*Correspondence: carlamarcas@hotmail.com

1 Department of Agronomy, Postgraduate Program in Agronomy, State University of Maringá, Avenida Colombo, 5790, Maringá, PR 87020-900, Brazil

Full list of author information is available at the end of the article
}

multiplicity of applications in human and animal nutrition, fulfilling a relevant socioeconomic role in many countries [39].

Soybean grains contain 40\% high-quality proteins, $20 \%$ lipids (including a high proportion of polyunsaturated fatty acids), 35\% carbohydrates, considerable levels of B vitamins, and $5 \%$ minerals (such as magnesium, phosphorus, iron, and zinc) [6]. Grains and derivatives are important sources of phenolic compounds-secondary metabolites synthesized by plants during normal development and in response to stress conditions, including pathogen infection. Phenolics are formed from 
phenylalanine and tyrosine and can be grouped into different classes, such as simple phenols, phenolic acids, flavonoids, coumarins, stilbenes, condensed and hydrolyzable tannins, and isoflavones [28]. Isoflavones have attracted great interest from researchers, health agencies, and the general population for their diverse biological properties, including antioxidant, radical scavenging, antifungal, estrogenic, and anticancer activities [43, 44].

Root-knot nematodes, such as Meloidogyne javanica (Treub) Chitwood and M. incognita (Kofoid \& White) Chitwood, are major limiting factors to soybean yield [40]. During feeding, the parasites inject esophageal secretions into plant tissues, causing hypertrophy and hyperplasia of xylem or cortical cells in the host root. This process leads to the formation of root galls, which alter root shape, affect water and nutrient transport, and, consequently, reduce vegetative growth [20]. Infected plants also show chlorotic spots on leaves and necrosis between leaf veins [10].

In the literature, there are several studies on the effects of nematode infection on plant physiology; however, little is known about the influence of parasitism on the composition and antioxidant potential of grains. Such information can contribute to our understanding of the physiological behavior of nematode-infected plants during reserve mobilization and grain filling. This study aimed to investigate the effect of different levels of $M$. javanica inoculation on vegetative growth, nematode parameters, yield, chemical composition, and antioxidant capacity in soybean.

\section{Methods}

\section{Soybean cultivation}

The experiment was carried out in a greenhouse with the coordinates $23^{\circ} 45^{\prime} 59^{\prime \prime} \mathrm{S} 53^{\circ} 19^{\prime} 30^{\prime \prime} \mathrm{W}, 442$ m elevation from November 2017 to March 2018 at 19 to $32{ }^{\circ} \mathrm{C}$. It was used a completely randomized design with four treatments (inoculum levels of $0,1000,2000$, and $4000 \mathrm{M}$. javanica eggs + eventual second-stage juveniles, J2). A total of 20 replications per treatment were cultivated (10 plants for evaluation of nematode and vegetative parameters and 10 plants for assessment of grain yield, chemical composition, and antioxidant capacity).

Soybean 'Pintado' seeds were sown in plastic pots containing $600 \mathrm{~mL}$ of a 2:1 mixture of soil and sand previously autoclaved at $120{ }^{\circ} \mathrm{C}$ for $2 \mathrm{~h}$. Three days before sowing, the soil was fertilized with $1 \mathrm{~g}$ of granular 16-1616 NPK (nitrogen/phosphorus/potassium) per pot. Sowing was carried out in the greenhouse by placing the seeds (two per pot) in holes in the soil. Plants were thinned to one per pot soon after emergence. Each plant was treated as an experimental unit.
Plants were inoculated with the respective inoculum levels at 7 days after sowing by addition of $4 \mathrm{~mL}$ of nematode suspension into four equidistant holes (about $3 \mathrm{~cm}$ deep) in the soil around the plant. Nematodes were obtained from a single-species population maintained on tomato plants. For extraction, tomato roots were collected with a trowel, ground in $0.05 \%(\mathrm{v} / \mathrm{v})$ sodium hypochlorite solution, and sieved through a 500 mesh sieve $[8,21]$. Inoculum levels were determined by counting nematodes in a Peters chamber under an optical microscope. During the experimental period, plants were irrigated two to three times a day, as required.

\section{Evaluation of vegetative and nematological parameters}

At 60 days after inoculation, half of the plants (10 replicates per treatment) were evaluated for vegetative and nematode parameters. Plants were harvested, and shoots were separated from roots. Shoot height was determined using a millimeter ruler. Shoot fresh and dry weights were assessed by gravimetry using a semi-analytical scale. For dry weight determination, shoots were dried in a forced air oven at $65^{\circ} \mathrm{C}$ for 3 days.

Roots were carefully washed to remove excess soil, and the root fresh weight was determined using a semianalytical balance. Subsequently, roots were subjected to nematode extraction using a blender and sodium hypochlorite solution, as proposed by Hussey and Barker (1973) and adapted by Boneti and Ferraz (1981). Total nematode number was determined by counting in a Peters chamber under an optical microscope. The number of nematodes per gram of root was calculated as the ratio between total nematode number and root fresh weight. The reproduction factor (RF) was determined as the quotient of final and initial nematode populations [31].

\section{Determination of grain yield parameters and proximate composition}

Ten plants per treatment were grown under greenhouse conditions until the end of the crop cycle (120 days). Then, grains were harvested and analyzed for number of pods per plant and thousand grain weight.

Harvested grains were ground in a rotary mill, homogenized, and analyzed in triplicate for moisture, ash, protein, lipid, and fiber contents. Results are expressed as $g$ $100 \mathrm{~g}^{-1}$ sample (dry basis-d.b.). Moisture content was assessed by oven drying at $105{ }^{\circ} \mathrm{C}$ to constant weight, and ash content was determined by calcination at $550{ }^{\circ} \mathrm{C}$ in a muffle oven. Protein content was determined by digestion with sulfuric acid $(98 \% \mathrm{v} / \mathrm{v})$, followed by distillation with sodium hydroxide $(50 \% \mathrm{v} / \mathrm{v})$ and titration with $\mathrm{HCl}$ $(0.1 \mathrm{M})$, according to the Kjeldahl method. Lipid contents 
were evaluated by Soxhlet extraction using petroleum ether. Fiber content was determined by the acid detergent digestion method [2].

\section{Analysis of total phenolic content, total flavonoids, and antioxidant capacity}

Soybean grains were harvested at the end of the crop cycle (120 days), and extractions were obtained by mixing $1 \mathrm{~g}$ of ground sample with $10 \mathrm{~mL}$ of $80 \%(\mathrm{v} / \mathrm{v})$ ethanol. The mixture was incubated on a shaker at $25^{\circ} \mathrm{C}$ and $150 \mathrm{rpm}$ for $6 \mathrm{~h}$, centrifuged at $3000 \mathrm{rpm}$ for $10 \mathrm{~min}$, and the supernatant was collected. The residue was washed with $10 \mathrm{~mL}$ of $80 \%$ ethanol and centrifuged. The supernatants were used as crude extract for analysis.

The total phenolic content of the extract was quantified by the Folin-Ciocalteu method [41] using a standard curve of gallic acid. Absorbance was measured at $760 \mathrm{~nm}$ on a spectrophotometer (Femto 700 Plus). Results were expressed as mg gallic acid equivalents (GAE) $100 \mathrm{~g}^{-1}$ sample.

Total flavonoids were quantified using $0.5 \mathrm{~mL}$ of extract and $150 \mu \mathrm{L}$ of $50 \mathrm{~g} \mathrm{~L}^{-1} \mathrm{NaNO}_{2}$. The mixture was incubated in a water bath at $50{ }^{\circ} \mathrm{C}$ for $5 \mathrm{~min}$ and received the addition of $15 \mu \mathrm{L}$ of $\mathrm{AlCl}_{3}$. After $5 \mathrm{~min}, 1.5 \mathrm{~mL}$ of $1 \mathrm{M}$ $\mathrm{NaOH}$ was added together with $1.5 \mathrm{~mL}$ of deionized water. Absorbance was read at $415 \mathrm{~nm}$ using a spectrophotometer. Total flavonoid content was calculated on the basis of a standard quercetin curve and expressed as mg quercetin equivalents (QE) $100 \mathrm{~g}^{-1}$ sample [7].

Antioxidant activity was evaluated by three methods. 2,2-Diphenyl-1-picrylhydrazyl (DPPH) radical scavenging activity was determined using an aliquot $(0.1 \mathrm{~mL})$ of each extract and $3.9 \mathrm{~mL}$ of DPPH ethanol solution. The absorbance was read at $517 \mathrm{~nm}$ using a spectrophotometer [9]. Ferric reducing antioxidant power (FRAP) assay was carried out using $90 \mu \mathrm{L}$ of extract, $270 \mu \mathrm{L}$ of distilled water, and $2.7 \mathrm{~mL}$ of FRAP reagent. After incubation at $37{ }^{\circ} \mathrm{C}$ for $30 \mathrm{~min}$, the absorbance was read at $595 \mathrm{~nm}$ [5]. Calibration curves for DPPH and FRAP assays were prepared with Trolox solution, and the results were expressed as $\mu \mathrm{mol}$ Trolox equivalents (TE) $\mathrm{g}^{-1}$ sample.

Superoxide radical $\left(\mathrm{O}_{2}{ }^{-}\right)$scavenging (SRS) activity was assessed by reacting each extract $(0.5 \mathrm{~mL})$ with $4 \mathrm{~mL}$ of $50 \mathrm{mM}$ Tris- $\mathrm{HCl}(\mathrm{pH} 8.2)$ and $0.5 \mathrm{~mL}$ of $25 \mathrm{mM}$ pyrogallol for $5 \mathrm{~min}$ at $25^{\circ} \mathrm{C}$. Then, $1 \mathrm{~mL}$ of $8 \mathrm{mM} \mathrm{HCl}$ was added, and the absorbance was read at $420 \mathrm{~nm}$. The scavenging percentage was calculated as follows: scavenging $\%=\left[A_{0}\left(A_{\mathrm{i}}-A_{\mathrm{j}}\right)\right] / A_{0} \times 100$, where $A_{0}$ is the absorbance of the control (prepared by adding Tris- $\mathrm{HCl}$ instead of sample), $A_{\mathrm{i}}$ is the absorbance of the sample, and $A_{\mathrm{j}}$ is the absorbance of the sample with pyrogallol [24].

\section{Isoflavone profile determination}

Isoflavone extraction was carried out in triplicate using crushed and defatted grains and a 1:1:1 (v/v/v) mixture of ultra-pure water, ethanol, and acetone as solvent [18]. Separation and quantification of isoflavones were performed by ultra-performance liquid chromatography (UPLC). The UPLC apparatus (Waters Corporation, Milford, MA, USA) was composed of an automatic injector (Acquity UPLC ${ }^{\circledR}$ System, Waters Corporation), a BEH reverse-phase C18 column $(2.1 \mathrm{~mm} \times 50 \mathrm{~mm}, 1.7 \mu \mathrm{m}$, Waters Corporation), and a diode array detector (Waters Corporation). The injection volume was $1.4 \mu \mathrm{L}$, the flow rate $0.3 \mathrm{~mL} \mathrm{~min}^{-1}$, and the column temperature $27^{\circ} \mathrm{C}$. The binary mobile phase consisted of $0.4 \%$ formic acid (A) and acetonitrile (B), and the elution gradient was as follows: $0 \mathrm{~min}, 95 \% \mathrm{~A}$; $8.5 \mathrm{~min}, 20 \% \mathrm{~A}$. Compounds were detected at $260 \mathrm{~nm}$. Retention times and UV spectra were compared with those of standards. Calibration curves were prepared for quantification purposes. Results were expressed as mmol g ${ }^{-1}$ sample [15].

\section{Statistical analysis}

Data were subjected to analysis of variance (ANOVA). To meet normality assumptions, as assessed by the Shapiro-Wilk test, we transformed nematode data using $\sqrt{x+1}$. Significant parameters were subjected to regression analysis at $p<0.05$, except protein, lipid, and fiber contents, which were analyzed at $p<0.10$. Analyses were performed using Sisvar [16].

\section{Results}

\section{Vegetative and nematological parameters}

Uninoculated plants had lower shoot height $(95 \mathrm{~cm})$ than plants inoculated with M. javanica $(p<0.05)$ (Fig. 1). In inoculated plants, shoot height increased with increasing inoculum levels up to 2450 eggs $+\mathrm{J} 2$ and then decreased slightly (Fig. 1a). Shoot fresh and dry weights showed similar behavior, with peaks of $51.83 \mathrm{~g}$ for fresh weight (Fig. 1b) and $13.91 \mathrm{~g}$ for dry weight (Fig. 1c) at 2583 and 2666 eggs $+\mathrm{J} 2$, respectively $(p<0.05)$.

Root fresh weight showed no statistical difference between treatments $(p<0.05)$; mean values ranged from $32.39 \mathrm{~g}$ in control plants to $33.21 \mathrm{~g}$ in plants inoculated with 4000 eggs $+\mathrm{J} 2$ (data not shown).

Nematode quantification (Fig. 2) revealed that the highest total number of nematodes $(73,765)$ is obtained with an initial population of about 3500 nematodes (Fig. 2a) $(p<0.05)$. The maximum number of nematodes per gram of root (2830) was estimated to be achieved with an initial population of 3642 eggs $+\mathrm{J} 2$ (Fig. 2b) 
$(p<0.05)$. Reproduction factor increased until reaching 34.85 at an inoculum level of 2433 eggs $+\mathrm{J} 2$, decreasing thereafter $(p<0.05)$.

\section{Yield and proximate composition}

Pod number per plant (Fig. 3a) and thousand grain weight (Fig. 3b) were lower in inoculated plants, regardless of inoculum level $(p<0.05)$, with minimum values of 6 pods plant $^{-1}$ at 1000 eggs $+\mathrm{J} 2$ and $103.90{\mathrm{~g} 1000 \text { grains }^{-1} \text { at }}$ 2625 eggs + J2. Overall, pod number decreased by 61.90 $71.42 \%$ and thousand grain weight by $14.61-17.85 \%$ in plants infected with $M$. javanica compared with nematode-free plants.

The proximate composition of soybean grains is presented in Fig. 4. The highest moisture content $(7.90 \mathrm{~g}$ $100 \mathrm{~g}^{-1}$ ) was found in grains from uninfected plants (Fig. 4a) $(p<0.05)$. Grains from infected plants had lower moisture content, regardless of inoculum level, with the

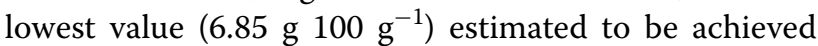
with an initial inoculum of 2250 eggs + J2. Protein, lipid, and fiber contents (depicted in Fig. $4 \mathrm{~b}-\mathrm{d}$, respectively) differed between treatments $(p<0.10$, respectively). The highest lipid content $\left(22.59 \mathrm{~g} 100 \mathrm{~g}^{-1}\right)$, found in grains from plants inoculated with the highest nematode level (4000 eggs $+\mathrm{J} 2)$, differed significantly from that of control grains. Inoculation of 1900 eggs $+\mathrm{J} 2$ was estimated to result in the maximum grain protein content $(44.64 \mathrm{~g}$ $100 \mathrm{~g}^{-1}$ ), whereas inoculation of 4000 eggs $+\mathrm{J} 2$ was predicted to provide the minimum protein content $(43.95 \mathrm{~g}$ $100 \mathrm{~g}^{-1}$ ). Fiber content decreased as the inoculum level

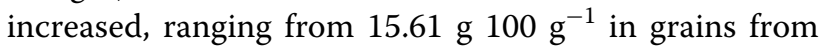

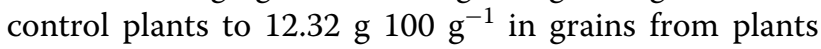
inoculated with 4000 eggs $+\mathrm{J} 2$. Inoculum level did not influence ash content, which ranged from 4.86 to $5.10 \mathrm{~g}$ $100 \mathrm{~g}^{-1}$ (data not shown).

\section{Total phenolic compounds, total flavonoids, and antioxidant capacity}

The levels of compounds associated with antioxidant activity in soybean were influenced by nematode inoculation (Fig. 5a). Grains harvested from inoculated plants had lower total phenolics; the lowest concentration (195.70 mg GAE $100 \mathrm{~g}^{-1}$ ) was estimated to be achieved with an inoculum level of 2158 eggs $+\mathrm{J} 2$ (Fig. 5a, $p<0.05)$. Total flavonoid content was found to decrease with increasing inoculum level up to 1700 eggs $+\mathrm{J} 2$. The lowest estimated content was $109.53 \mathrm{mg}$ QE $100 \mathrm{~g}^{-1}$ (Fig. 5b). At higher inoculum levels, total flavonoid content increased, and at 4000 eggs $+\mathrm{J} 2$, flavonoid content was higher than that in the uninoculated control $(p<0.05)$.

The lowest DPPH $\left(123 \mu \mathrm{mol} \mathrm{TE}^{-1}\right.$, Fig. $\left.5 \mathrm{c}\right)$ and FRAP (7.72 $\mu \mathrm{mol} \mathrm{TE} \mathrm{g}^{-1}$, Fig. $5 \mathrm{~d}$ ) activities were detected in soybean grains from plants inoculated with 2000 eggs $+\mathrm{J} 2(p<0.05)$. By the SRS method, the minimum value was $25.47 \%$ in grains of plants inoculated with 900 eggs + J2 (Fig. 5e). Similar to the behavior observed for total flavonoids (Fig. 5b), DPPH and SRS activities increased after reaching the minimum value; the highest antioxidant activity $\left(140.15 \mu \mathrm{mol} \mathrm{TE} \mathrm{g}^{-1}\right.$ for DPPH and $32.76 \%$ for SRS) was obtained by inoculation of 4000 eggs $+\mathrm{J} 2$.

\section{Isoflavone profile}

Of the 12 most well-known soybean isoflavones, 11 were identified in this study (Table 1 ). There was a significant difference in malonylgenistin $(p<0.05)$, acetylglycitin $(p<0.05)$, and genistin $(p<0.05)$ levels between treatments. The highest content of these isoflavones was observed at an initial population of 4000 eggs $+\mathrm{J} 2$. Total isoflavone content did not differ between treatments $\left(2.43\right.$ to $\left.2.72 \mathrm{mmol} \mathrm{g}^{-1}\right)$. The following isoflavone profile was observed: $58 \%$ malonyl- $\beta$-glucosides, $20 \%$ $\beta$-glucosides, $13 \%$ aglycones, and $9 \%$ acetyl- $\beta$-glucosides. The only undetected form was acetyl- $\beta$-genistin.

\section{Discussion}

Vegetative growth was highest in plants inoculated with low levels of $M$. javanica. This compensatory response of plants to nematode infection can be seen as a form of acquired defense. Plants activate defense responses when attacked by herbivores or pathogens, altering gene expression and metabolism [42]. However, at very high nematode levels, roots become more damaged and are unable to supply sufficient amounts of water and nutrients, affecting plant growth [14].

The results of root fresh weight can be explained by nematode-induced formation of root galls. It should be noted that root development in infected soybean plants varies according to nematode aggressiveness and the efficiency of plant responses to such infections [1].

Nematode population growth as a function of initial population followed the expected patterns: small inoculum levels resulted in exponential growth, whereas large inoculum levels affected nematode multiplication, probably because of nutrient competition and other environmental limitations [36].

The reduction in yield, a reflection of the reduction in pod number, was also expected, as pod number depends on the number of flowers produced during the reproductive period. One of the symptoms shown by 

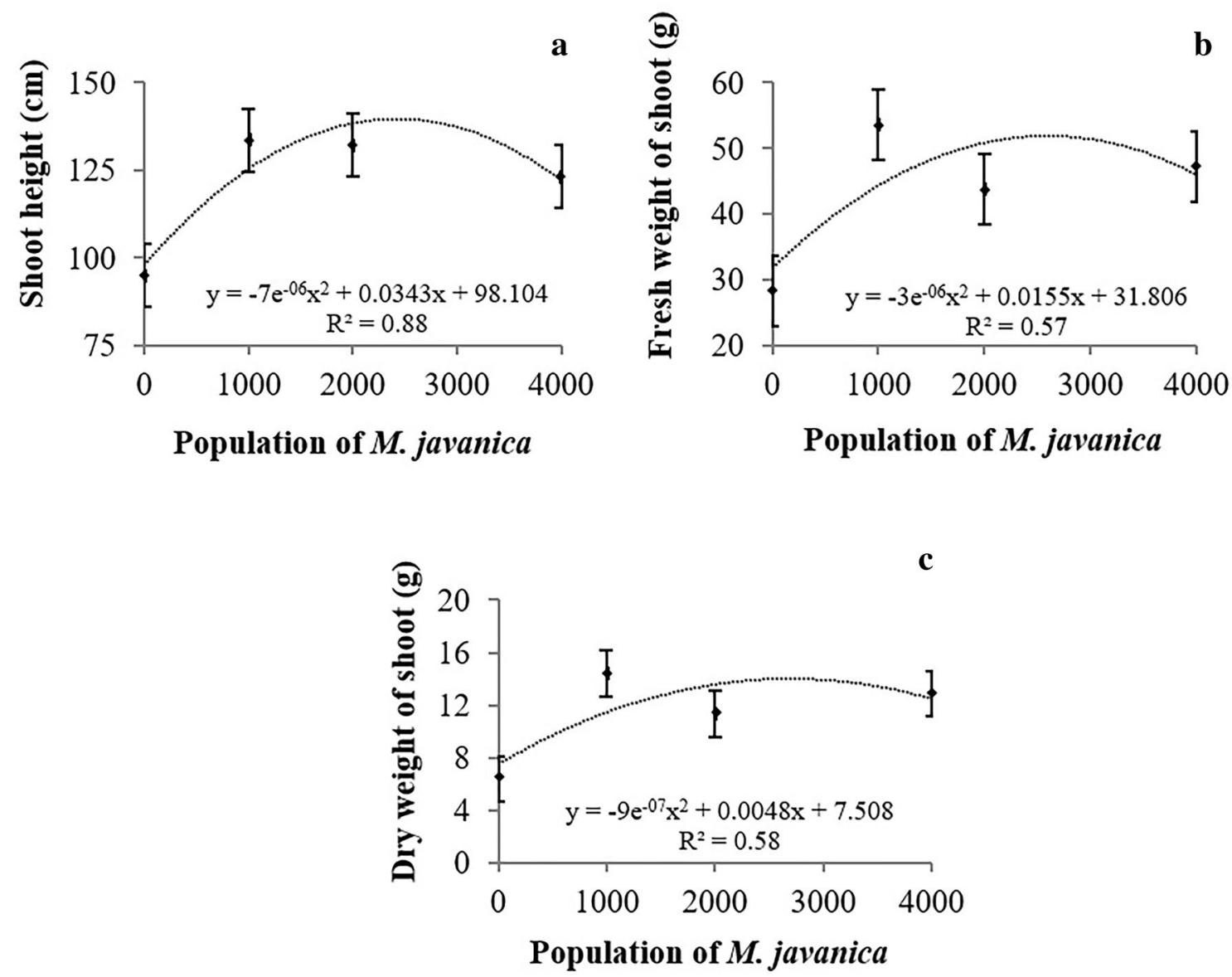

Fig. 1 Vegetative parameters of soybean plants relative to initial population of Meloidogyne javanica after 60 days inoculation. a Shoot height (cm); b fresh weight of shoot (g); c dry weight of shoot (g). Significant at $5 \%$ probability

nematode-infested plants is an intense abortion of flowers and pods [27]. A similar greenhouse study assessing the effects of Pratylenchus brachyurus inoculum level (up to 2000 individuals) on soybean found that yield and pod number decreased by about $24 \%$ in inoculated plants [11].

The mean thousand grain weight of uninoculated plants (about $133 \mathrm{~g}$ ) was similar to that of conventional soybean cultivated in different regions and at different sowing times (137-180 g) [12, 37]. Reduction in grain weight in nematode-infested plants can be attributed to photosynthesis impairment caused by root damage [30].

The protein content of soybean grains from inoculated and uninoculated plants agrees with values (31.70-

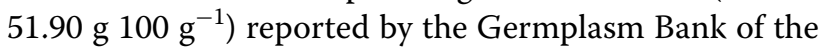
Brazilian Agricultural Research Corporation [35]. However, we observed that protein content decreased with increasing inoculum levels. It is known that protein synthesis in plants is a complex process that occurs at several stages and locations. Variations in environmental conditions throughout plant development can decrease protein levels by interrupting protein synthesis and favoring that of other compounds [29]. Protein synthesis can be reduced by up to $20 \%$ in plants subjected to water stress at the beginning of the reproductive phase [25].

The lipid contents observed in this study (21.13$22.59 \mathrm{~g} 100 \mathrm{~g}^{-1}$ ) were similar to those found in conventional and transgenic soybean grains (8.00-25.40 g $100 \mathrm{~g}^{-1}$ ) [22] and in grains from plants infected by $P$. brachyurus (20.91-22.53 g $100 \mathrm{~g}^{-1}$ ) [11]. Lipids not only contribute to cell structure and energy reserves, but also serve as precursors to intracellular or long-distance signaling compounds, which are crucial for the activation of plant defense systems against adverse abiotic conditions [38]. An important factor to be considered is that certain conditions may favor lipid synthesis in detriment to that of proteins, as these biosynthetic processes compete for carbon chains [34]. Soil liming was shown to increase lipid but decrease protein content in soybean grains proportionally to the increase in soil $\mathrm{K}_{2} \mathrm{O}$ [46]. 

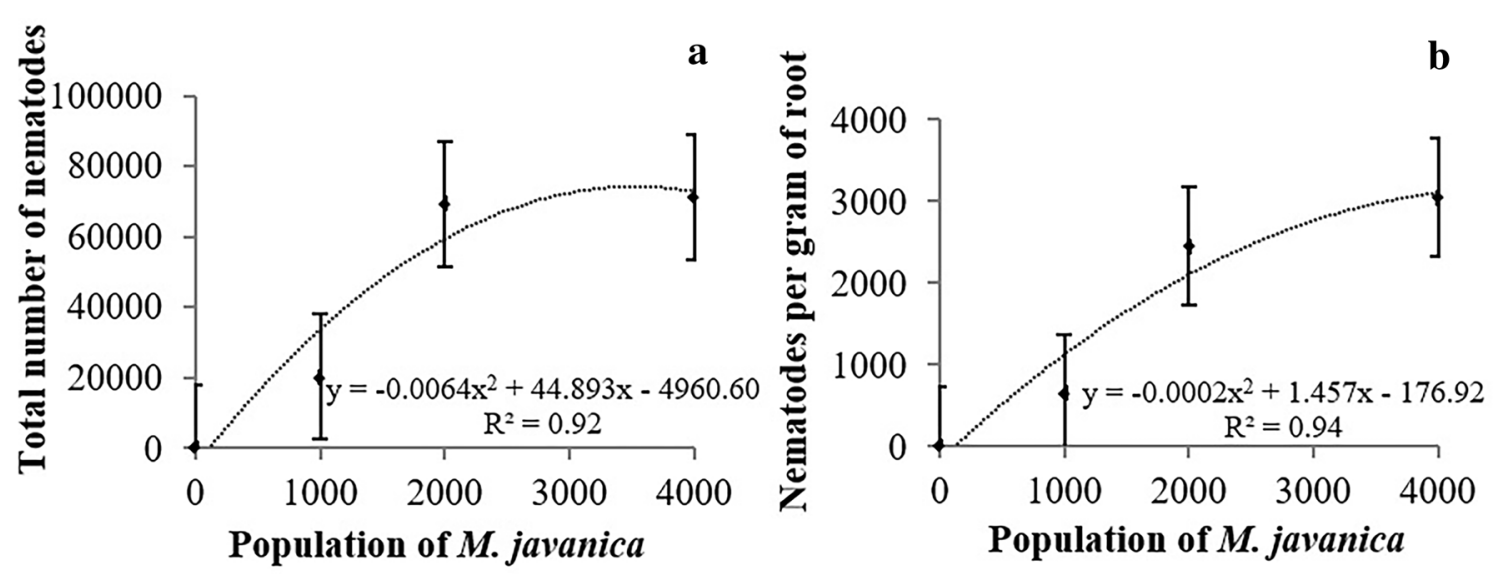

C

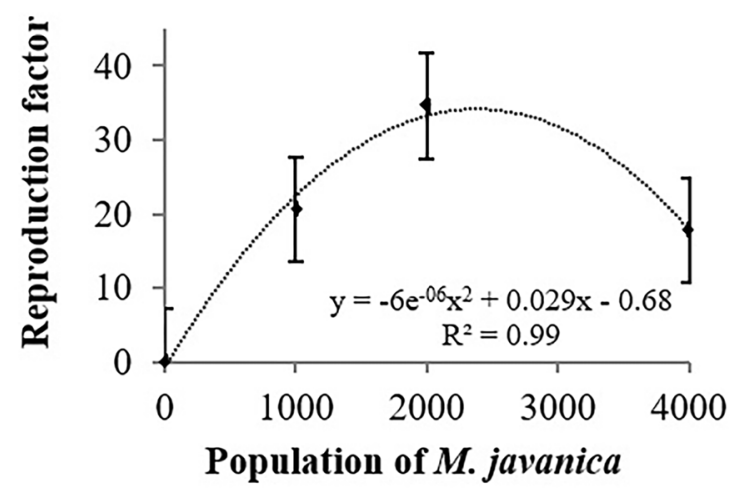

Fig. 2 Nematological parameters of Meloidogyne javanica in soybean relative to initial population after 60 days inoculation -a total number of nematodes; $\mathbf{b}$ nematodes per gram of root; $\mathbf{c}$ reproduction factor. Significant at $5 \%$ probability
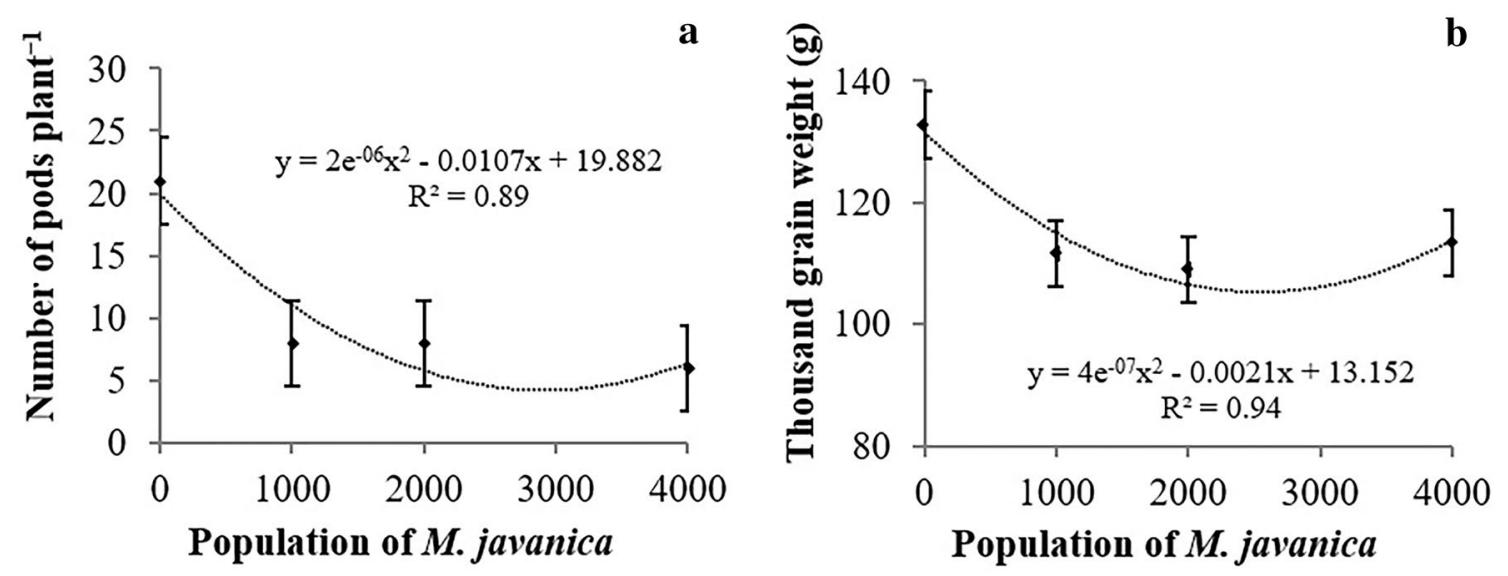

Fig. 3 Productivity parameters to initial population of Meloidogyne javanica after 120 days of inoculation - a number of pods plant ${ }^{-1} ; \mathbf{b}$ thousand grain weight (g). Significant at $5 \%$ probability 

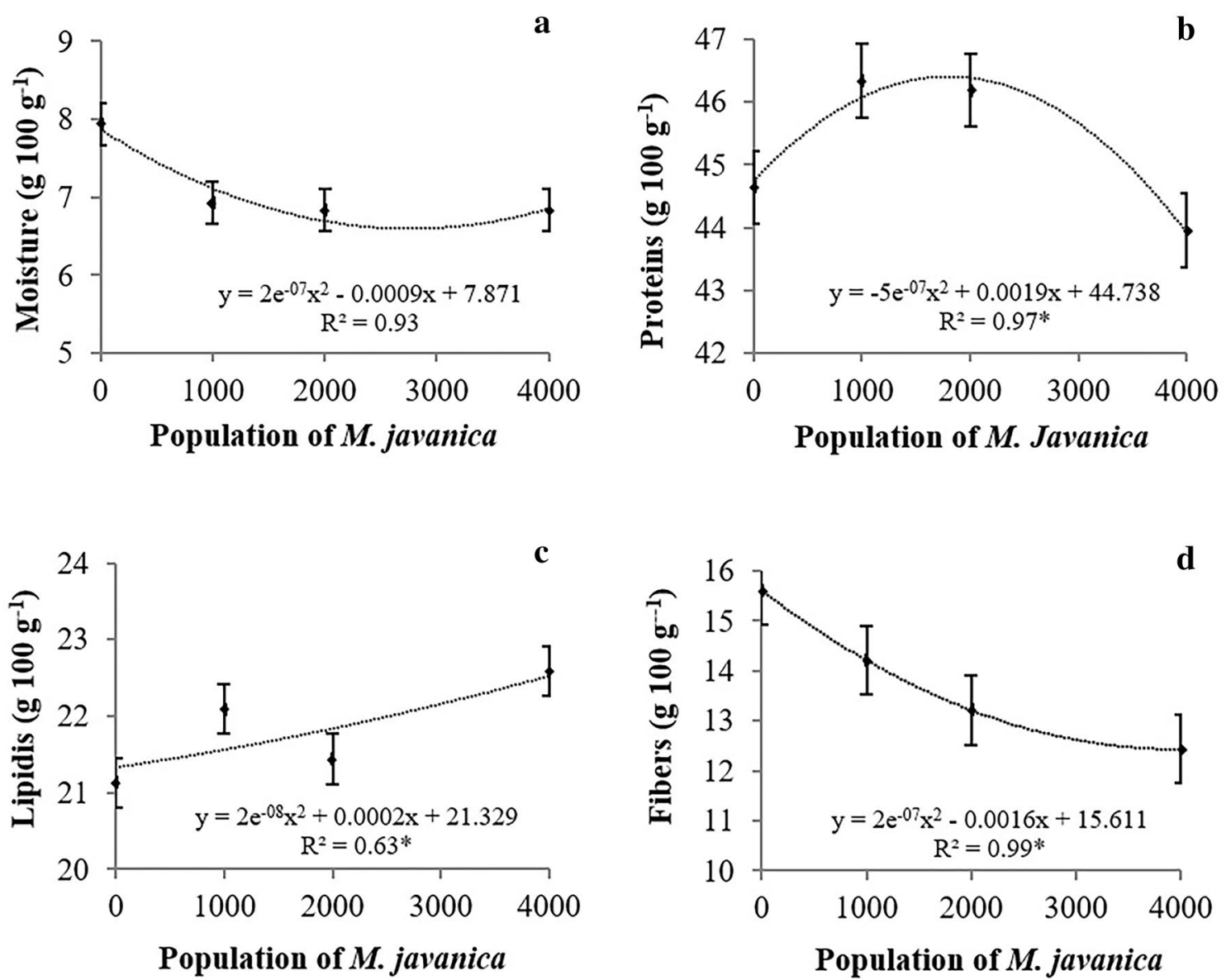

Fig. 4 Proximal composition ( $100 \mathrm{~g}^{-1}$ ) of soybean grains relative to initial population of Meloidogyne javanica after 120 days of inoculation. a Moisture, $\mathbf{b}$ proteins, $\mathbf{c}$ lipids, d fibers. Significant at $5 \%$ probability, ${ }^{*}=$ significant at $10 \%$

Soybean grain fiber content decreased with increasing $M$. javanica inoculum levels, probably because of the reduction in grain size. Soybean fibers are concentrated mainly in grain hulls and are synthesized during grain filling. Insufficient nutrient accumulation resulting from nematode infection can reduce grain size and, consequently, fiber content. Dietary fibers are of great nutritional importance and have received much attention in the last three decades [26].

The reduction in total phenolics and flavonoids with increasing population levels up to 2000 eggs $+\mathrm{J} 2$ is suggestive of phytochemical translocation to other plant organs, such as leaves, stems, and roots, where the demand for antioxidants is likely to be greater. This conclusion is based on the hypothesis that active compounds are concentrated where most needed during plant defense responses to maximize adaptation to the environment [3]. However, the stress caused by abrupt or intense biotic or abiotic stimuli can change the natural functioning of organisms, leading to diverse responses, such as acclimatization and genetic modifications [32]. High inoculum levels might have subjected plants to intense stress, altering biosynthesis and translocation of phenolic compounds to grains, as observed in plants inoculated with more than 3000 eggs $+\mathrm{J} 2$.

There was a direct relationship of antioxidant capacity, particularly FRAP activity, with total phenolics and flavonoids (Fig. 5). This relationship is commonly observed in fruits and vegetables [23]. Higher levels of total phenolics and flavonoids indicate a higher capacity to scavenge free radicals (DPPH), reduce metal ions (FRAP), and sequester superoxide anions $\left(\mathrm{O}_{2}{ }^{-}\right)$.

The isoflavone profile of soybean grains (Table 1) showed that synthesis of certain types of isoflavones may vary according to nematode inoculum level. Nevertheless, total isoflavone content was not affected. Total isoflavone levels ranged from 0.50 to $1.20 \mathrm{mg} \mathrm{g}^{-1}$, in agreement with literature data $\left(0.10-5 \mathrm{mg} \mathrm{g}^{-1}\right)$ [45]. Isoflavone distribution seemed to be related to the biosynthesis order of compounds. Malonyl-CoA is an 


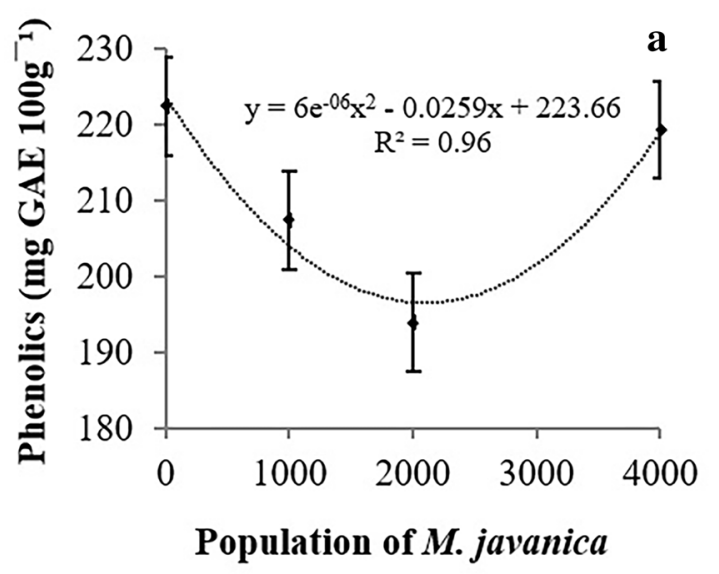

c

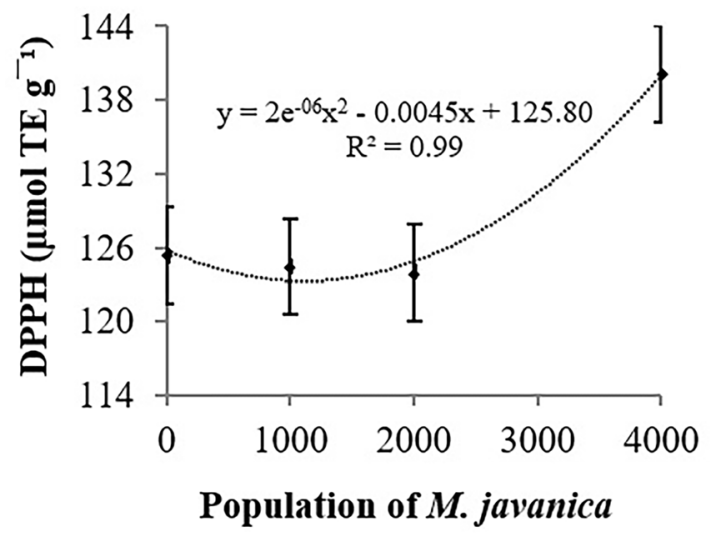

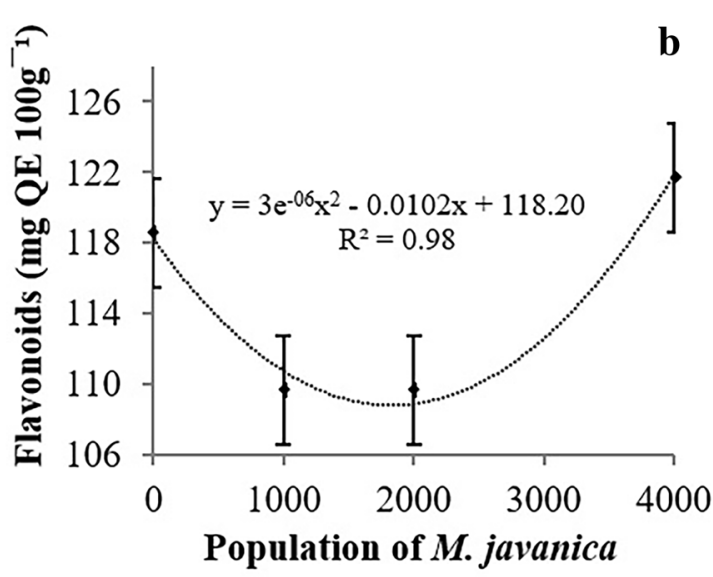

d

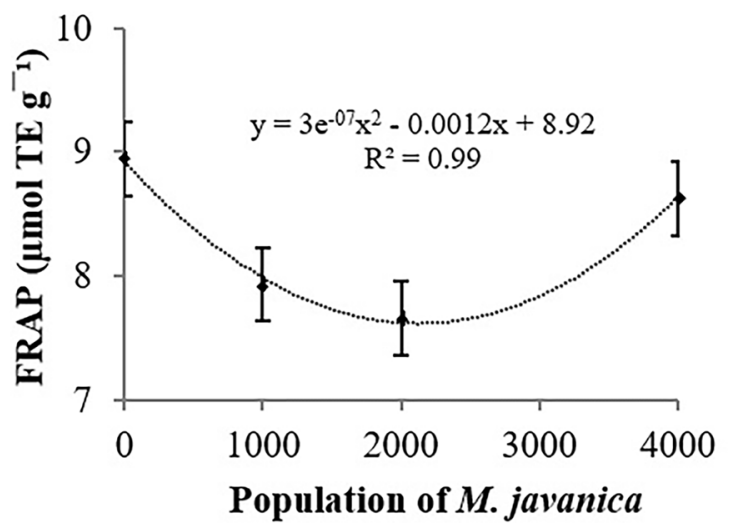

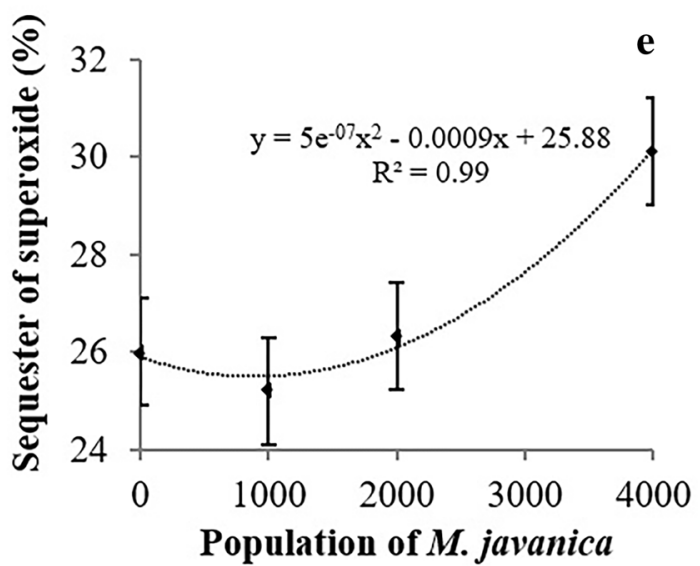

Fig. 5 Total phenolics compounds (mg GAE $100 \mathrm{~g}^{-1}$ ) (a), total flavonoids (mg QE $\left.100 \mathrm{~g}^{-1}\right)(\mathbf{b})$, antioxidant capacity by DPPH (c), FRAP (d) $(\mu \mathrm{mol}$ $\mathrm{TE}^{-1}$ ) and sequester of superoxide radicals (\%) (e) of the soybean grains relative to initial population of Meloidogyne javanica after 120 days of inoculation. Significant at 5\% probability

intermediate in the formation of chalcones, which are isomerized to originate flavanones ( $\beta$-glucoside structures). These structures are converted into aglycones by the action of $\beta$-glucosidase [47]. A predominance of malonyl forms and $\beta$-glucosides has been observed in previous studies, with malonyl- $\beta$-glucosides accounting for 70 to $80 \%$ of soybean isoflavones and $\beta$-glucosides for $25 \%[4,13]$.

It is interesting to note that aglycone forms are the most suitable for human consumption because of their high 
Table 1 Isoflavone profile $\left(\mathrm{mmol} \mathrm{g}^{-1}\right)$ from soybean infected with $M$. javanica

\begin{tabular}{|c|c|c|c|c|c|c|}
\hline \multirow[t]{2}{*}{ Isoflavone } & \multicolumn{4}{|c|}{ Initial population (eggs $+\mathrm{J} 2$ ) } & \multirow[t]{2}{*}{ CV (\%) } & \multirow[t]{2}{*}{$\mathrm{R}^{2}$} \\
\hline & 0 & 1000 & 2000 & 4000 & & \\
\hline Mal-Daidzin & 664 & 689 & 651 & 701 & 14.29 & ns \\
\hline Mal-Glicitin & 339 & 353 & 353 & 354 & 13.57 & ns \\
\hline Mal-Genistin & $485 b$ & $521 b$ & $396 b$ & $539 a$ & 6.85 & 0.36 \\
\hline Acet-Daidzin & 131 & 147 & 118 & 151 & 9.79 & ns \\
\hline Acet-Glicitin & $94 b$ & $99 \mathrm{~b}$ & $82 b$ & $106 a$ & 9.16 & 0.55 \\
\hline Daidzin & 197 & 206 & 176 & 207 & 16.07 & ns \\
\hline Genistin & $65 b$ & $76 b$ & $66 b$ & $87 a$ & 8.29 & 0.26 \\
\hline Glicitin & 217 & 215 & 242 & 218 & 8.70 & ns \\
\hline Daidzein & 171 & 163 & 183 & 185 & 14.81 & ns \\
\hline Genistein & 71 & 79 & 79 & 84 & 12.18 & ns \\
\hline Glicitein & 86 & 82 & 82 & 87 & 18.78 & ns \\
\hline Total & 2520 & 2640 & 2428 & 2719 & 10.29 & ns \\
\hline
\end{tabular}

ns not significant at $5 \%$ probability. Different letters on the same line indicate statistical difference at 5\% probability. Mal malonyl- $\beta$-glycoside, Acet acetyl- $\beta$-glycoside

bioavailability and activity. Isoflavones can be converted by heat or enzymatic hydrolysis. Heat conversion, which normally occurs during product processing, increases the bioactivity of isoflavones by enhancing liposolubility and reducing molecular weight, thereby contributing to their absorption through the intestinal wall $[17,33]$. As thermal treatment was not used in this study, isoflavone conversion may have occurred in the plant via enzymatic hydrolysis. $\beta$-Glucosidases convert glucoside forms into aglycones and hydrolyze preformed isoflavones (malonyl-glucosyldaidzein and malonyl-glucosyl-genistein), releasing precursor molecules, such as glyceollin and coumestrol, in response to physical, chemical, and biological stresses [48]. Although no significant differences were found between treatments, we observed a relationship between aglycone structures and nematode population levels, suggesting the occurrence of isoflavone conversion in response to biotic stress. Analysis of glyceollin levels in soybean extracts could contribute to testing this hypothesis.

Flavonoids, such as isoflavones, are secondary metabolites with the ability to scavenge free radicals; they are produced in situations of metabolic imbalance or stress [19]. Given that aglycone isoflavones are highly bioavailable, grains of soybean plants inoculated with nematodes may serve as sources of aglycones for human consumption.

\section{Conclusions}

Soybean plants were susceptible to $M$. javanica at the evaluated inoculum levels. Vegetative parameters were negatively affected by the highest population levels, whereas yield decreased at all inoculation levels. Grain moisture, fiber, and protein contents decreased and lipid content increased with increasing inoculum level. Total phenolic and flavonoid contents were lower in grains from plants inoculated with low nematode levels (up to about 2000 eggs $+\mathrm{J} 2$ ) and higher in grains from plants inoculated with high nematode levels. A positive correlation was observed between antioxidant capacity and total phenolic and flavonoid contents. Nematode infection altered the isoflavone profile of soybean grains. Further studies are needed to understand the influence of nematodes on isoflavone accumulation in soybean.

\section{Abbreviations}

J2: Second-stage juvenile; GAE: Gallic acid equivalents; QE: Quercetin equivalents; DPPH: 2,2-Diphenyl-1-picrylhydrazyl; FRAP: Ferric reducing antioxidant power; TE: Trolox equivalents; ANOVA: Analysis of variance; SRS: Superoxide radical scavenging.

\section{Acknowledgments}

The authors would like to thank the State University of Maringá and State University of Londrina for providing the facilities.

\section{Authors' contributions}

All authors contributed equally to the research and agree with the submission of the manuscript to the journal. All authors read and approved the final manuscript.

\section{Funding}

This research did not receive any funding.

Availability of data and materials

Additional data are available on request from the corresponding author.

Ethics approval and consent to participate

Ethical approval and consent to participate were not required for this research, as it did not involve human or non-human animals.

Consent for publication

Not applicable. 


\section{Competing interests}

The authors have no conflict of interest to declare.

\section{Author details}

${ }^{1}$ Department of Agronomy, Postgraduate Program in Agronomy, State University of Maringá, Avenida Colombo, 5790, Maringá, PR 87020-900, Brazil. 2 Department of Agricultural Sciences, Postgraduate Program in Agricultural Sciences, State University of Maringá, Estrada da Paca, s/n, São Cristóvão, Umuarama, PR 87502-970, Brazil. ${ }^{3}$ Department of Food Science and Technology, State University of Londrina, Rodovia Celso Garcia Cid, PR445 km 380, PO Box 10.001, Londrina, PR 86057-970, Brazil. ${ }^{4}$ Department of Technology, State University of Maringá, Avenida Ângelo Moreira da Fonseca, 1800, Umuarama, PR 87506-370, Brazil.

Received: 3 November 2020 Accepted: 7 January 2021

Published online: 12 February 2021

\section{References}

1. Almeida FA, Carvalho RM, Leite MLT, Fonseca WL, Pereira FF. Reação de cultivares de soja aos nematoides das galhas. Rev Ciênc Agr. 2016;59:228-34

2. AOAC - Association of Official Analytical Chemists. Official Methods of analysis-AOAC International. 2016;20:3000

3. Atkinson NJ, Dew TP, Orfila C, Urwin PE. Influence of combined biotic and abiotic stress on nutritional quality parameters in tomato (Solanum lycopersicum). J Agric Food Chem. 2011;59:9673-82.

4. Barbosa ACL, Lajolo FM, Genovese MI. Influence of temperature, $\mathrm{pH}$ and ionic strength on the production of isoflavone-rich soy protein isolates. Food Chem. 2006;98:757-66.

5. Benzie IFF, Strain JJ. The ferric reducing ability of plasma (FRAP) as a measure of "antioxidant power": The FRAP assay. Anal Bioc. 1996;239:70-6.

6. Bischoff TZ, Coelho SRM, Schoeninger V, Cassol FDR, Do Prado NV, Christ D. Technological quality of soybean oil obtained from stored grain under controlled environmental conditions. Eng Agríc. 2016;36:1145-56.

7. Boateng J, Verghese M, Walter LT, Ogutu S. Effect of processing on antioxidant contents in selected dry beans (Phaseolus spp. L.). Leb-Wiss Technol. 2008:20:1-8.

8. Boneti JIS, Ferraz S. Modificação do método de Hussey \& Barker para extração de ovos de Meloidogyne exigua em raízes de cafeeiro. Supl Fito Bras. 1981;6:553.

9. Brand-Williams W, Cuvelier ME, Berset C. Use of a free radical method to evaluate antioxidant activity. Leb-Wiss Technol. 1995;28:25-30.

10. Brida AL, Gabia AA, Pezzoni Filho JC, Moraes DAC, Wilcken SRS. Variabilidade espacial de Meloidogyne javanica em soja Meloidogyne javanica em soja. S Phytopathol. 2016;42:175-9.

11. Castanheira CM, Falcão HG, Ida El, Dias-Arieira CR, Barros BCB. Pratylenchus brachyurus parasitism on soybean: effects on productivity, vegetative and nematological parameters and chemical properties. Eur J Plant Pathol. 2020;157:651-61

12. Dalchiavon FC, Carvalho MP. Correção linear e espacial dos componentes de produção e produtividade de soja. Semina. 2012:33:541-52.

13. Devi MKA, Kumar SS, Giridhar P. LC-ESI-MS based characterization of isoflavones in soybean (Glycine max (L.) Merr) from India. J Food Sci Tech. 2018;55:5045-54

14. Escobar C, Barcala M, Cabrera J, Fenoll C. Overview of root-knot nematodes and giant cells. In: Escobar C, Fenoll C. Plant Nematode interactions-view on compatible interrelationships. Adv Bot Res. 2015;73:1-32.

15. Falcão HG, Handa CL, Silva MBR, Camargo AC, Shahidi F, Kurozawa $L E$, Ida El. Soybean ultrasound pre-treatment prior to soaking affects $\beta$-glucosidase activity, isoflavone profile and soaking time. Food Chem. 2018;269:404-12.

16. Ferreira DF. Sisvar: a computer statistical analysis system. Ciênc Agrotecnol. 2011;35:1039-42

17. Góes-Favoni SP, Carrão-Panizzi MC, Beleia A. Changes in isoflavone in soybean cotyledons soaked in different volumes of water. Food Chem. 2010;119:1605-12.

18. Handa CL, Couto UR, Vicensoti AH, Georgetti SR, Ida El. Optimization of soy flour fermentation parameters to produce $\beta$-glucosidase for bioconversion into aglycones. Food Chem. 2014;152:56-65.
19. Heck Cl, Shcmalko M, Mejia EG. Effect of growing and drying conditions on the phenolic composition of mate teas (Ilex paraguariensis). J Agric Food Chem. 2008:56:8394-403.

20. Hussain M, Kamran M, Singh K, Zouhar M, Rysanék P, Anwar SA. Response of selected okra cultivars to Meloidogyne incognita. Crop Prot. 2016;82:1-6.

21. Hussey RS, Barker KRA. Comparison of methods for collecting inocula of Meloidogyne spp. including a new technic. Plant Dis Rep. 1973;57:1025-8.

22. Kamizake NKK, Novacki C, Zaia DAM. Determinação de proteínas e lipídios totais, umidade, cinzas, macro ( $\mathrm{Ca}, \mathrm{Mg}, \mathrm{K}$ ) e micro elementos (Fe, Cu, Mn, Zn) em cultivares de soja [Glycine max (I.) Merrill] não-transgênicas e transgênicas. Semina. 2006;27:175-81.

23. Kuligowski M, Pawłowska K, Jasińska-Kuligowska I, Nowak J. Isoflavone composition, polyphenols content and antioxidative activity of soybean seeds during tempeh fermentation. CYTA J Food. 2017;15:27-33.

24. Liu J, Wen $X Y$, Zhang $X Q$, Pu HM, Kan J, Jin CH. Extraction, characterization and in vitro antioxidant activity of polysaccharides from black soybean. Int J Biol Macromol. 2014:72:1182-2119.

25. Lobato AKS, Oliveira Neto CF, Santos Filho BG, Costa RCL, Cruz FJR, Neves HKB, Lopes MJS. Physiological and biochemical behavior in soybean (Glycine max cv. Sambaiba) plants under water déficit. Aust J Crop Sci. 2008;2:25-32.

26. Mudgil D, Barak S. Composition, properties and health benefits of indigestible carbohydrate polymers as dietary fiber: a review. Int J Biol Macromol. 2013:61:1-6.

27. Mundstock CM, Thomas AL. Soja: fatores que afetam o crescimento e o rendimento dos grãos. Evangraf. 2005;1:31.

28. Naczk M, Shahidi F. Extraction and analysis of phenolics in food. J Chromatogr A. 2004;1054:95-111.

29. Naoe AML, Peluzio JM. Sousa JP Estresse ambiental na cultura da soja Rev Int Univ. 2017:12:16.

30. Oliveira AS, Da Silva RA. Occurrence and pathogenicity of Meloidogyne javanica on Teak (Tectona grandis Linn. F.) plants. Ciênc Flor. 2013;23:563-9.

31. Oostenbrink M. Major characteristics of the relation between nematodes and plant. Meded. 1996:66:1-46.

32. Palacios C, Serra D, Torres P. Papel ecológico dos metabólitos secundários frente as estresse abiótico. In: Lopez AM, Nagai A, Furlan CM. Botânica no inverno. 2013. Inst Bioc Univ São Paulo. 2013;1:52-59.

33. Park MH, Jeong MK, Kim MJ, Lee JH. Modification of isoflavone profiles in a fermented soy food with almond powder. J Food Sci. 2012;77:128-34.

34. Pípolo AE, Sinclair TR, Camara GMS. Protein and oil concentration of soybean seed cultured in vitro using nutrient solutions of differing glutamine concentration. Ann Appl Biol. 2004;144:223-7.

35. Pípolo AE, Hungria M, Franchini JC, Balbinot Junior AA, Debiasi $H$, Mandarino JMG. Teores de óleo e proteína em soja: fatores envolvidos e qualidade para a indústria. Embrapa Soja. 2015;86:16.

36. Rocha FS, Pinheiro JB, Campos HD, Campos VP. Relação entre populações iniciais de Meloidogyne javanica e Heterodera glycines e do desenvolvimento do sistema radicular da soja. Nematol Bras. 2008;32:161-6.

37. Santos HP, Fontaneli RS, Pires J, Lampert EA, Vargas AM, Verdi AC. Rendimentos de grãos e características agronômicas de soja em função de sistemas de rotação de culturas. Bragantia. 2014:73:263-327.

38. Schroeder Jl, Allen GJ, Hugouvieux V, Kwak JM, Waner D. Guard cell signal transduction. Annu Rev Plant Physiol Plant Mol Biol. 2001;52:627-58.

39. Silva JB, Carrão-Panizzi MC, Prudêncio SH. Chemical and physical composition of grain-type and food-type soybean for food processing. Pesq Agropec Bras. 2009;44:777-84

40. Silva RA, Nunes NA, Santos TFS, Iwano FK. Effect of crop rotation and crop sequences for the management of soybean nematodes in sandy soil. Nematropica. 2018;48:198-206.

41. Swain T, Hillis WE. The phenolic constituents of Prunus domesticathe quantitative analysis of phenolic constituents. J Sci Food Agric. 1959;10:63-8.

42. Taiz L, Zeiger E, Møller IM, Murphy A. Plant physiology and development. Sinauer. 2014:6:761.

43. Thomas AJ, Ismail R, Taylor-Swanson L, Cray L, Schnall JG, Mitchell ES, Woods NF. Effects of isoflavones and amino acid therapies for hot flashes and co-occurring symptoms during the menopausal transition and early postmenopause: a systematic review. Maturitas. 2014;78:263-76. 
44. Tranche S, Brotons C, Pisa BPDL, Macias R, Hevia E, Marzo-Castillejo M. Impact of a soy drink on climacteric symptoms: an open-label, crossover, randomized clinical trial. Gynecol Endocrinol. 2016;36:477-82.

45. United States Department of Agriculture. USDA Database for the Isoflavone Content of Selected Foods, Release 2.1. 2015. https://www.ars.usda. gov/ARSUserFiles/80400525/Data/isoflav/Isoflav_R2-1.pdf. Accessed: 27 Jan 20

46. Veiga AD, Von Pinho EVR, Veiga AD, Pereira PHAR, Oliveira KC, Von Pinho RG. Influencia do potássio e da calagem na composição química, qualidade fisiológica e na atividade enzimática de sementes de soja. Ciên Agrotecnol. 2010;34:953-60.
47. Yu O, McGonigle B. Metabolic and engineering of isoflavone biosynthesis Adv Agron. 2005;86:147-90.

48. Zhou YY, Luo SH, Yi TS, Li CH, Luo Q, Hua J, Liu Y, Li SH. Secondary metabolites from Glycine max and their growth inhibitory effect against Spodoptera litura. J Agric Food Chem. 2001;59:6004-10.

\section{Publisher's Note}

Springer Nature remains neutral with regard to jurisdictional claims in published maps and institutional affiliations.

\section{Submit your manuscript to a SpringerOpen ${ }^{\circ}$ journal and benefit from:}

- Convenient online submission

- Rigorous peer review

- Open access: articles freely available online

- High visibility within the field

- Retaining the copyright to your article

Submit your next manuscript at $\boldsymbol{\nabla}$ springeropen.com 